\title{
Five causes why boron essentiality on humans has not been confirmed: A hypothesis
}

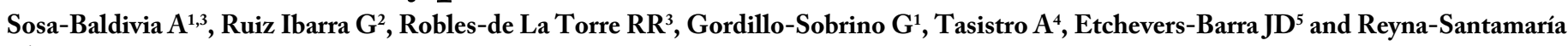
$\mathbf{L}^{6}$

${ }^{1}$ Nutrilite S de RL de CV. Mexico Ave \# 8, Rancho E1 Petacal, Municipality of Tolimán, Jalisco, Mexico

${ }^{2}$ Instituto Tecnológico Superior de Tamazula de Gordiano, Jalisco, México

${ }^{3}$ CIBA-Tlaxcala, Hacienda San Juan Molino Km 15 Carretera Estatal Tecuexcomac-Tepetitla, Mexico

${ }^{4}$ International Plant Nutrition Institute (IPNI). 3500 Parkway Lane, Suite 550 Peachtree Corners, GA, USA

${ }^{5}$ Colegio de Postgraduados (COLPOS), Carretera México-Texcoco Km. 36.5, Montecillo, Texcoco 56230, Montecillos estado de México, México

${ }^{6}$ Colegio Superior Agropecuario del Estado de Guerrero (CSAEGRO). Km 14.5 Carretera Iguala-Balsas, Cocula Guerrero México

\begin{abstract}
On human nutrition, Boron (B) is classified in the category of possible essential elements; this means that its essentiality has not been proven and various causes have prevented it. The objective of this review was to analyze the next five causes that have possibly prevented to demonstrate the essentiality of B in humans: (1) Low daily requirement of B; (2) High number of sources to supply B in diet (3) Short life expectancy of humans (LEH); (4) Lack a method to diagnose B in vivo and; (5) Lack an area with low intake of $B$. Because the requirement of $B$ in humans is very low $\left(1.0 \mathrm{mg} \mathrm{day}^{-1}\right)$, in trials of nutrition all sources of $\mathrm{B}$ should be controlled. Because a deficiency of $\mathrm{B}$ inhibits the synthesis of the active form of vitamin $\mathrm{D}$, known as Calcitriol $\left(1,25-(\mathrm{OH})_{2}-\mathrm{D}_{3}\right)$ and assimilation of Ca on humans, osteoporosis $(\mathrm{OST})$ and arthritis (ART) could be diseases associated with a deficit of B. In the past, the short LEH (47 years) prevented that OST and ART were identified as symptoms of B deficit; however today the LEH is 73 years, under this situation, is possible that the mineral reserve on bones is not sufficient to ensure the properly body function, therefore incidence of OST and ART on the population could be increasing, especially in areas with low intake of B. On the other side, B hair analysis is a usefully diagnostic tool which could be used in experiments to demonstrate B essentiality on humans; these experiments should be conducted in areas where the population has low intake of $\mathrm{B}$ along with high incidence of OST and ART.
\end{abstract}

\section{Introduction}

The importance of boron (B) in plant nutrition was demonstrated in USA by Katherine Warington in 1923, and as soon as this occurred, also it began to study its essentiality in animals and human [1]. The first attempts to induce deficiencies of $\mathrm{B}$ in animals were conducted between 1939 and 1944 [2] and at the present its essentiality has been proven in diatoms, cyanobacteria, algae, actinomycetes of Frankia genus, fish and frogs [3-6] and although there are evidences of its beneficial effects on humans, it essentiality has still not been accepted [7]. Taking the lack of epidemiological evidence into consideration WHO (World Health Organization) put B in the possible essential elements category and this could be a sign that with a major number of studies, from a nutritional point of view, it could prove that $B$ is an essential element [8]. This statement is associated to the fact that several researchers agree that an ingest a up to $2-6 \mathrm{mg} \mathrm{B} \mathrm{day}^{-1}$ helps to prevent arthritis (ART), osteoporosis (OST), osteoarthritis, cervical cancer, prostate cancer and cardiovascular diseases in people older than 45 years [7,913]. At the light of these evidences, several countries of the European Community (EC), England, Canada, USA and Australia where the B intake is lower than $3 \mathrm{mg} \mathrm{day}^{-1}$, have allowed the sale of B supplements; this as a way its population can meet their daily requirement of $B$ [2]. Reviewing this topic, we founded that an agronomist wrote about the B importance on the human nutrition; why? Well, like many other people we were unaware the importance of $B$ in human nutrition. It was until 2012 when I (the first author) had interest to study it; this because my rheumatism pain disappeared three months after I starting to change my diet to increase the amount of B. As a man of science, I look for a scientific explanation for this event, so after analyzing the climatic conditions, food and water that I had consumed before (I was living in San Juan de Abajo Nayarit) and after I moved to San Quintin BC; for that time I also read the three articles published on the theme [14-16] I considered that a high amount of B present in my diet (mainly on water, fruits and vegetables) caused that my rheumatism disappeared. During the past 35 years, the B has been subject to an intense study to demonstrate its essentiality $[1,2]$ and even though it has not been possible this, in vitro experiments and in vivo assays in animal and human have all shown that B is a bioactive element in nutrition and metabolism issues; certain amounts of B have important advantages on human health: bone growth, central nervous system function, alleviates arthritic symptoms, facilitates hormone action and moreover, its intake is associated with a reduced risk for some types of cancer [17]. Even with all this evidence, today most nutritionists do not consider the B an element essential; because of this, even though

Correspondence to: Sosa-Baldivia A, Nutrilite S de RL de CV. Mexico Ave \# 8, Rancho El Petacal, Municipality of Tolimán, Jalisco, Mexico; CIBA-Tlaxcala, Hacienda San Juan Molino Km 15 Carretera Estatal Tecuexcomac-Tepetitla, Mexico; E-mail: Anacleto.sosa@amway.com

Key words: boron, essentiality, nutrition, man

Received: November 18, 2016; Accepted: December 13, 2016; Published: December 16, 2016 
it has been established that B has beneficial bioactivity in humans, it generally has received limited attention or mention when dietary guidelines or intake recommendations are formulated [18]. Recently, to compare some studies related to B nutrition in animals and humans with those conducted to demonstrate the essentiality of $\mathrm{Mo}$ and $\mathrm{Cl}$ in plants $[19,20]$ we found that many of the obstacles that prevented to demonstrate the essentiality of B on human's match with those that in the past preventing to prove the essentiality of the $\mathrm{Mo}$ and $\mathrm{Cl}$ in plants. Based on the aforementioned, the objective of this work review was to analyze five causes that possibly have prevented to demonstrate the $\mathrm{B}$ essentiality on humans: 1) Low daily requirement of B; 2) High number of sources of B in daily diet; 3) Short human life expectancy; 4) Lack a method to diagnose B in vivo; and 5) Lack of an area with low intake of B. It should be noted that the first two obstacles were extensively reviewed by researchers of Grand Forks Human Nutrition Research Center in North Dakota USA [21,22].

\section{Low daily requirement of $B$}

Currently, out of the 118 known elements, 93 are found in the nature [23], 59 are present in the human body, and in a person of $70 \mathrm{~kg}$, there are about of $18 \mathrm{mg}$ of B, that is $0.00003 \%$ of weight alive [24]. In accordance with Broyer et al. [19] the human requires ingesting at least $1.0 \mathrm{mg} \mathrm{day}^{-1}$, considering that on average, an adult man ingests $3.0 \mathrm{~L}$ water and $0.347 \mathrm{~kg} \mathrm{day}^{-1}$ of foods (dry basis) [25,26], the concentration of $\mathrm{B}$ in a regular diet is of $0.00003 \%$; this value is difficult to manage in nutrition tests, especially when are evaluating intakes less than $1.0 \mathrm{mg}$ $B$ day $^{-1}$ [27]. To solve this situation, Hunt [21] recommended the use of water deionized, as well as filtering the air to eliminate $B$, using free borosilicate containers; and also, taking in account the B provided by products of hygiene and personal care. The suggestions made by Hunt, have been put in practice in experiments of $B$ nutrition and as reference is the work made by Sutherland et al. [28].

\section{High number of sources to supply $B$ in the daily intake}

$B$ is an element widely spread all over nature, it is present in any part of the environment $[29,30]$ and the sources supplies are so varied that in tests of nutrition is difficult to control all of them [21]. The control of all sources to supply B on the diet is very difficult because, besides of the B contained in water, air, soil and food (plant and animal), it is in hygiene products and personal care such as detergents, soaps, shampoos, creams and toothpaste [22]; in addition, glass and ceramic utensils also contain B that easily integrates to hot liquid foods [21] as it occurs in the laboratory when the samples are contaminated to use material with a high content of borosilicate [31,32]. Due to the large number of sources that supply and the low requirement of B (1.0 $\mathrm{mg}$ day $^{-1}$ ) to date have not been able to identify at least a symptom associated with its deficit, or well to demonstrate it participates in any reaction biochemical in the metabolism of the man [30]. However, several authors suggest the OST and ART are diseases could be related with a $\mathrm{B}$ deficit $[14,17,33-35]$; however, because $\mathrm{Ca}$ is $66 \%$ of the mass bone [36,37], currently OST are more associated with a deficiency of this element $[38,39]$ that the B deficiency. The hypothesis that OST and ART could be related to a deficit of $B$ is based considering people suffer these diseases present $50 \%$ less concentration of B in bones and blood than healthy people $[14,34,35]$; grounded on these evidences, since 22 years ago several physicians ha be recommended the $B$ supplementation as part of the OST and ART treatment $[9,14,34,35,40]$. There are no data to support that the assimilation of $\mathrm{Ca}$ and $\mathrm{B}$ occur at the same time but recently Jugdaohsingh et al. [36] reported that the accumulation and desorption pattern of both elements in bones through the life cycle of rats is very similar. B presents high capacity to combine with hydroxyl groups, therefore, it can to participate in several biochemical reactions [41] and in the metabolism of humans, it participates in the reaction of the hydroxylation that occurs on the kidneys which gives rise to the active form of vitamin D known as Calcitriol (1,25- $(\mathrm{OH}) 2-\mathrm{D} 3)$ [42]. When Newnham [43] developed the hypothesis that B could be essential, he considered that their assimilation is closely associated $y$ both elements are accumulated mainly in the bones $[36,44,45]$. Apparently Newnham [43] had sense, because the adequate supply of $\mathrm{Ca}$ alone does not prevent OST and on countries such as USA, Canada and England where the intake of $\mathrm{Ca}$ is high, the population presents more incidence of OST than population of countries where the intake of Ca is lower $[46,47]$. Several factors are related with the assimilation of $\mathrm{Ca}$ on humans; however, from the point of nutritional view, the status of vitamin D is most important [47,48]; and more specifically could be the status of $B$, because in animals with hipovitaminosis besides of Vitamin $\mathrm{D}$, the $\mathrm{B}$ is the only factor that can alleviate it and improve the assimilation of $\mathrm{Ca}[49,50]$; This clearly suggests that in animals B could be the key in Ca assimilation [51]; today the recommendation is to supply B to prevent physiological disorders related to $\mathrm{Ca}$ deficiencies in humans such as OST and ART [11,52].

\section{Short human life expectancy}

The life expectancy on humans (LEH) from 47 years in 1960 passed to 75 years in 2015 [53], and with a balanced nutrition could be 120 years [54]. The continuous improvement of LEH on the last 66 years suggests that in the past the LEH too short did not allow to detect the B relevance on the human nutrition. In 1963, when [43] hypothesized B could be essential, the LEH was 47 years; considering the pattern of loss of bone mass $[37,55]$ at this age the mineral reserve accumulated in bones was still sufficient to ensure the proper functioning of the skeletal system, this explains why on this time the incidence of OST was quite low, and the high incidence of ART reported in some regions during this time could be related to B deficit [15], because under conditions of malnutrition, this etiology occurs before a subject could reach 37 years of life [56]. On the 90s decades, the LEH was 72 years and it was observed that the OST incidence increased so high it was recognized as main cause of fractures in adults over 50 years old. The impact of OST in the human health was so big, that in 1998 was funded the International Osteoporosis Foundation and one year after the Asociacion Mexicana del Metabolism Oseo y Mineral $[57,58]$ whose main goal was to study the origin and clinical management of diseases of the skeletal system. After 2010, the incidence of bone diseases had increased widely because the LEH became 75 years, the bone mineral reserve was not sufficient for ensure their properly function [59]. The tendency on the LEH indicates it will continue to increase, therefore quite sure the incidence of OST and ART will continue increasing too. This fact suggests that in the past was not possible to determine the essentiality of the B in the man because his biological cycle was shorter and paradoxically, to the actual did not allow to find response to B supplementation. But in the next few year, this will change because in order to demonstrate the essentiality of $\mathrm{B}$, the long LEH actual could help to reproduce symptoms of deficiency of B on humans.

\section{Lack a method to diagnosis B in vivo}

The lack of a method to determine the concentration of $\mathrm{B}$ in vivo is a cause that has prevented to associate at least a symptom with $B$ deficit on humans. According to Alexander et al. [45], because B is mainly accumulated in the skeletal system; the bones are the best tissue to diagnose the nutritional status of B on humans and animals. 
Currently, the determination of B in bones is only done in animals and humans died [36,45]; this is because is no possible to collect samples of bones in ribs, femur, column and parietal in vivo. Two alternate methods to determine the B content in vivo are the analysis of blood and urine $[34,35,60]$; however, because both methods just can diagnose the nutritional status of 24 hours, is no possible to use them to identify etiologies associated with a deficit of B in the long term [61]. The homeostatic mechanism that regulates the concentration of $B$ in humans is so dynamic that subjects who have different daily B intake present little variation in the content of $\mathrm{B}$ in blood and urine [62]. According to Vanderpool et al. [63], 95\% of B ingested is absorbed in one hour, $50 \%$ is eliminated in the urine, and the rest is disposed between 72 and 96 hours [64]. Therefore, although the B present in blood and urine is related with the amount of B consumed [28], the metabolism regulates the amount of $B$ present in the bloodstream, and for example, increasing the B intake 9 times $(0.36 \mathrm{mg}$ to $3.0 \mathrm{mg})$ only increases 1.5 times the $\mathrm{B}$ concentration in blood (5.72 to 8.79 um B L) [27]. Fortunately, the hair analysis is a technique currently used to diagnose the nutritional status of $B$ on the long term [31,60]; According to Bass et al. [61]; this method is better than the urine and blood analysis because it reflects the nutrition status of B for several years; is more accurate, easy and secure to collect, store and analyze samples. In the future, the analysis of B in hair will be a tool that could help to determine the relationship of $B$ nutritional status with and incidence of OST, ART another disease of the bones on humans.

\section{Lack an area with low intake of $B$}

At the present, has not been located a region where the B intake is less than $1.0 \mathrm{mg} \mathrm{day}^{-1}$, this situation has not permitted to find response in experiments with $B$ supplementation. In the past, the poor knowledge of $B$ in the human health conducted that [65] established a permissible level of $B$ in drinking water of $0.3-0.5 \mathrm{mg} \mathrm{B} \mathrm{L}^{-1}$, this value was so impractical that the European Community (EC) could not meet with this rule, and changed it to $1.0 \mathrm{mg} \mathrm{B} \mathrm{L}^{-1}$, and permitted that their members countries to adjust it on basis of the quality of its water sources [66]. Germany had no problem to meet the standard [67]; England changed it to $2.0 \mathrm{mg} \mathrm{B} \mathrm{L}^{-1}$, and Italy although adopted the English standard was flexible to regions like the Tuscany where the water contains between $4-8 \mathrm{mg} \mathrm{B} \mathrm{L}^{-1}$ could adjust it [68]. In order to take such decision, the EC is supported on studies conducted in Turkey where is found that the intake of 13-29 mg B day ${ }^{-1}$ has not adverse effects on long term in humans [69-71]. It is evident to demonstrate the B essentiality we will need to operate the antithesis of the studies conducted in Turkey and the first step is to find a region where the B intake is less of $1.0 \mathrm{mg}$ day $^{-1}$. In accordance with the biogeochemical cycle of B [29], regions with low levels of B in the environment (air, water and soil) usually are far of sea, volcanoes, contaminated cities, industrial areas and located in high altitudes (at least 2000 meters above sea level). In Mexico, the municipality of San Felipe del Progreso, State of Mexico is a region that, besides to comply with the requirements aforementioned, $10 \%$ of its population exhibits arthritis to early age (37 years) [56]. As like as San Felipe del Progreso, the population of the municipality of Chankom Yucatán, also exhibits high incidence of arthritis (2.8 times more than the average national) and severe malnutrition [56,72,73]; Currently it is not known what is the B nutritional status in both population; but their low consumption of fruits and vegetables leads us to think that it is low. In theory the population of these two regions could be candidates to conduct experiments of $B$ supplementation in order to confirm if ART is a disease related to B deficiency in humans. In order to try to demonstrate the $\mathrm{B}$ essentiality on the human nutrition, in the next three years we will conduct a research project where will be to use all information discussed on this paper. Currently, the first steps to demonstrate the $\mathrm{B}$ essentiality were completed and the more important are: 1) The classification of B by WHO as possible essential element; (2) Demonstrate that the intake of $29 \mathrm{mg} \mathrm{day}^{-1}$ has not an impact in health to long term; (3) Know that Australia, a country which initially declared toxic the consumption of $\mathrm{B}$ has now revoked this decision; (4) Achieve that even without their essentiality fully accepted, countries as USA, Canada, England and Australia allow the sale of B supplements. Based on all information previously presented, it is evident that the next studies should be directed to demonstrate the essentiality of $B$, to do so, the following points should be considered: a) All sources contributing to the B daily intake should be monitored, considering the low requirement of B; b) Taking in account OST and ART are probably caused by a deficit of $B$, the subjects to study must are living in regions with low intake of $B$ and high incidence of ART and OST.; and (c) The use of hair analysis for B, will be valuable tool to diagnosis the nutritional status of B in a long term. Finally when I first read, 26 years ago the story how W. Reed discovered the agent transmitter of yellow fever virus; which certainly did not, but just confirmed that C. Finlay claimed several years before [74]; the question that arises from my mind is: will there be happening the same thing with B? about Newnham's hypothesis and that of Finlay hypothesis about Yellow Fever Virus resulted of an empiric assumption with no scientific data to support it, perhaps it could also be true, because the B deficit affecting negatively the production of vitamin $\mathrm{D}$ also inhibits the assimilation of $\mathrm{Ca}$ that could cause diseases of the skeletal system such as OST and ART, and other ones in a long term. There is no doubt that B essentiality will be demonstrated, the scientific bases were established by researchers as R. Newnham, F. Nielsen, C. Hunt, R. Scorei and many others that have not desisted in their attempt to prove that $\mathrm{B}$ is not only essential to plants and lower organisms; but it is also for higher animals and humans. The last step of this challenge will not be easy because we must experimentally replicate and scientifically explain what naturally occur in Italy, Cyprus, Israel, Spain and Australia, where the high intake of B $[2,14,66]$ along with the long $\mathrm{LE}$ of its population (85 years) [75] is an unequivocal proof that $\mathrm{B}$ is important in human nutrition.

\section{Conclusions}

Daily requirement of $B$ is so low (at least $1.0 \mathrm{mg} \mathrm{day}^{-1}$ ), that in experiments of nutrition with $B$ on humans will be necessary to control all sources to supply this element on human diet. Because nutritional status of $\mathrm{B}$ on humans affect the synthesis of the vitamin $\mathrm{D}$ and assimilation of $\mathrm{Ca}$, OST and ART could be associated with the deficit of B on humans. In the past, LE was less than 47 years, this avoided OST and ART as symptoms of deficit of B were expressed; however, today the actual LE is 75 years, so reserve of $\mathrm{B}$ and $\mathrm{Ca}$ on bones will not be enough to ensure their properly function and incidence of OST and ART diseases will increase, this fact will help to determine the beneficial effect of $\mathrm{B}$ on the human health on the short term. It is possible to use hair analysis as a diagnostic tool to determine the status of B on humans in experiments of supplementation with B to demonstrate its essentiality. These experiments could be conducted in areas where the low intake of B and the high incidence of OST and ART are common on the population.

\section{References}

1. Sosa-Baldivia A, Ruiz-Ibarra G, Etchevers-Barra JD (2016) Will boron be essential for human nutrition? Arch Lat Nutr 66: 82-83.

2. Meacham S, Karakas S, Wallace A, Altun F (2010) Boron in human health: evidence for dietary recommendations and public policies. Open Miner Process J 3: 36-53. 
3. Rezanka T, Sigler K (2008) Biologically active compounds of semimetals. Phytochemistry 69: 585-606. [Crossref]

4. Bolaños L, Lukaszewski K, Bonilla I, Blevins D (2004) Why boron? Plant Physiol Biochem 42: 907-912. [Crossref]

5. Rowe RI, Eckhert CD (1999) Boron is required for zebrafish embryogenesis $J$ Exp Biol 202: 1649-1654. [Crossref]

6. Fort DJ, Stover EL, Strong PL, Murray FJ, Keen CL (1999) Chronic feeding of a low boron diet adversely affects reproduction and development in Xenopus laevis. $J$ Nutr 129: 2055-2060. [Crossref]

7. Pizzorno L (2015) Nothing Boring About Boron. Integr Med (Encinitas) 14: 35-48. [Crossref]

8. Bakirdere S, Orenay S, Korkmaz M (2010) Effect of boron on human health. Open Miner Process J 3: 54-59.

9. Downey M (2016) Boron reduces prostate cancer risk. Life Extension Collector's edition 125-130.

10. Price CT, Langford JR, Liporace FA (2012) Essential Nutrients for Bone Health and a Review of their Availability in the Average North American Diet. Open Orthop J 6: 143-149. [Crossref]

11. Miljkovic D, Miljkovic N, McCarty MF (2004) Up-regulatory impact of boron on vitamin D function -- does it reflect inhibition of 24-hydroxylase? Med Hypotheses 63 1054-1056. [Crossref]

12. NHPDHC (National Health Products Directorate Health Canada) (2007) Boron as a natural ingredient in natural health products.

13. Strum BS (2003) Boron maintains bones, joints, neurons and may reduce prostate cancer risks. LE Magazine.

14. Newnham RE (1994) Essentiality of boron for healthy bones and joints. Environ Health Perspect 102 Suppl 7: 83-85. [Crossref]

15. Newnham ER (1984) Boron is essential-it corrects and prevents arthritis. NZTEG. Conference Massey University, Palmerston, North.

16. Newnham ER (1981) Mineral imbalance and boron deficiency. In: Trace elements metabolism in man and animals (TEMA-4). In: Howell JMcC, Gawthorne JM, White CL, eds. Canberra, Australia. Aust Acad Sci pp: 400-402.

17. Nielsen FH (2014) Update on human health effects of boron. J Trace Elem Med Biol 28: 383-387. [Crossref]

18. Nielsen F (2014) Should bioactive trace elements not recognized as essential, but with beneficial health effects, have intake recommendations. J Trace Elem Med Biol 28 (4): 406-408. [Crossref]

19. Broyer TC, Carlton AB, Johnson CM, Stout PR (1954) Chlorine-A Micronutrient Element for Higher Plants. Plant Physiol 29: 526-532. [Crossref]

20. Arnon DI, Stout PR (1939) Molybdenum as an Essential Element For Higher Plants. Plant Physiol 14: 599-602. [Crossref]

21. Hunt DC (1996) Dietary boron deficiency and supplementation. Chapter 14. In Methods in nutrition research a new CRC series on research in nutrition. R.R. Watson ed. CRC Press. Boca Raton, FL, USA. 229-253.

22. Hunt CD, Shuler TR, Mullen LM (1991) Concentration of boron and other elements in human foods and personal-care products. J Am Diet Assoc 91: 558-568. [Crossref]

23. Velázquez-Monroy LM, Ordorica-Vargas MA (2016) Composición química de los seres vivos. $12 \mathrm{p}$.

24. John E (1998) The Elements. Clarendon Press. 3rd ed. Oxford, England.

25. Grandjean A (2004) Water requirements, impeding factors, and recommended intakes. World Health organization.

26. Anke M, Müller M, Glei M, Hilling-Gunther H, Trüpschuch A, et al. (1997) Zinc intake and zinc balance of adults in central Europe- depending on time, sex, living area, eating habits, age and live weight. In: Trace elements in Man and Animals-9: Proceeding of the Ninth international Symposium on Trace Elements in Man an Animals. P.W.F. Fischer, M.R.L. Abbé, K.A. Cockell, and R.S. Gibson. NRC Research Press. Ottawa, Canada pp: $160-165$

27. Hunt DC (2007) Dietary boron: evidence for essentiality and homeostatic control in humans and animals. Adv plant Animals Boron Nut: 251-267

28. Sutherland B, Woodhouse RL, Strong P, King JC (1999) Boron balance in humans. J Trace Elem Exp Med 12: 271-284.
29. Park H, Schelsinger HW (2002) Global biogeochemical cycle of boron. Global Biogeochemical Cycles 16: 1-11.

30. FNB (Food Nutrition Board) (2001) Dietary reference intakes for boron. Institute of Medicine. National Academy Press. Washington DC, USA.

31. Watts LD (2007) Boron-a clinical review. Newsletter 11: 1-3

32. Sah NR, Brown HP (1997) Boron determination -A review of analytical methods Microchem J 56: 285-304.

33. Ince S, Arslan-Acaroz D (2015) An update on health effects of metalloid trace element boron. Aperito J drug Design Pharmacol 2: 1-6.

34. Ali-Mahmood NM, Barawi OR, Hussain SA (2016) Relationship between serum concentration of boron and inflammatory markers, disease duration, and severity of patients with knee osteoarthritis in Sulaimany city. Natl J physiol Pharm Pharmacol 6: $27-31$

35. Al-Rawi SZ, Gorial IF, Shammary AW, Mushin F, Al-naaimi SA, Kareem S (2012) Serum boron concentration in arthritis: correlation with disease activity, functiona class, and rheumatoid factor. J Exp Integr Med 3: 9-15.

36. Jugdaohsingh R, Pedro LD, Watson A, Powell JJ (2014) Silicon and boron differ in their localization and loading in bone. Bone Rep 1: 9-15. [Crossref]

37. de la Torre W (2015) El calcio en la prevención y tratamiento de Osteoporosis. 12-140 p: In: Osteoporosis 2015. W. Aguirre, W. de la Torre y R Jervis (eds). Soc Ecuat Metab Miner Quito, Ecuador.

38. Sánchez A, Puche R, Zeni S, Oliveri B, Galich MA, et al. (2002) El papel del calcio y de la vitamina D en la salud ósea (parte 1). Reemo 11: 201-217.

39. Schurman L, Bagur A, Claus-Hermberg H, Messina OD, Negri AL, et al. (2013) Guidelines for the diagnosis, prevention and treatment of osteoporosis, 2012. Medicina (B Aires) 73: 55-74. [Crossref]

40. Kelly SG (1997) Boron a review of its nutritional interactions and therapeutic uses Altern Med Rev 2(1): 48-56.

41. Nielsen HF (1988) Boron an overlooked element of potential nutritional importance Nutr Today January-February. 1-7.

42. Vielma RJ, Mora MM, Marino AO, Hernández G, Linares JL, Urdaneta RH, Arévalo GE (2012) Estudio comparativo de la excreción urinaria de boro, calcio, magnesio y fósforo en mujeres posmenopáusicas con y sin osteoporosis. Invest Clin 53: 3 - 15 .

43. Newnham ER (2003) Boron: major cause and cure for arthritis. Nutrition 92.

44. Moseman RF (1994) Chemical disposition of boron in animals and humans. Environ Health Perspect 102 Suppl 7: 113-117. [Crossref]

45. Alexander GV, Nusbaum RE, MacDonald ns (1951) The boron and lithium content of human bones. $J$ Biol Chem 192: 489-496. [Crossref]

46. WHO (World Health Organization) (2003) Boron in drinking-water, Background document for preparation of WHO guidelines for drinking-water quality. Tech. Report. Geneva, Switzerland.

47. Fusco SW (2016) Osteoporosis: not a normal part of aging.

48. Bellan M, Pirisi M, Sainaghi PP (2015) [Osteoporosis in Rheumatoid Arthritis: role of the vitamin D/parathyroid hormone system]. Rev Bras Reumatol 55: 256-263. [Crossref]

49. Hunt CD, Herbel JL, Idso JP (1994) Dietary boron modifies the effects of vitamin D3 nutrition on indices of energy substrate utilization and mineral metabolism in the chick. J Bone Miner Res 9: 171-182. [Crossref]

50. Hunt DC, Nielsen HF (1981) Boron and cholecalciferol in the chick. In: Trace element metabolism in man and animals (TEMA-4). Howell JMcC, Gawthorne JM, White CL, eds. Canberra, Australia. Aust Acad Sci pp: 597-600.

51. Nielsen HF (1991) The saga of boron in food: from a banished food preservative to a beneficial nutrient for humans. Current Topics Plant Biochem Physiol 10: 274-286.

52. Vora P (2016) Calcium and osteoporosis. Health Positive pp: 41-43.

53. Inegi (Instituto Nacional de Geografía y Estadística) (2016) Esperanza de vida en México. https://www.cuentame.inegi.org.mx.

54. Knapton S (2015) World's first anti-ageing drug could see humans live to 120 . The Telegraph.

55. Bonjour JP, Chevalley T, Ferrari S, Rizzoli R (2009) The importance and relevance of peak bone mass in the prevalence of osteoporosis. Salud Publica Mex 51 Suppl 1: 


\section{S5-17. [Crossref]}

56. Heimgartner E, Rosenthal M (1979) Rheumatoid arthritis in an Indian population (Mazahua) in the Mexican plateau. Bol Oficina Sanit Panam 86: 283-292. [Crossref]

57. IOF (International Osteoporosis Foundation) (2016).

58. AMMOM (Asociación Mexicana del Metabolismo Óseo y Mineral) (2016). http:// www.ammom.mx/

59. IOF (International Osteoporosis Foundation). 2012. The Latin America Regional audit Epidemiología, costos e impacto de la osteoporosis.

60. DDI (Doctors Data Inc) (2016) Toxic and essential assessment of key minerals and harmful metals.

61. Bass DA, Hickock D, Quig D, Urek K (2001) Trace element analysis in hair: factors determining accuracy, precision, and reliability. Altern Med Rev 6: 472-481. [Crossref]

62. Hunt DC, Butte FN, Johnson KL (2005) Boron concentrations in milk from mothers of exclusively breast-fed healthy full-term infants are stable during the first four months of lactation. Human Nutr Metab: 2383-2386.

63. Vanderpool RA, Hoff D, Johnson EP (1994) Use of inductively coupled plasma-mass spectrometry in Boron-10 stable isotope experiments with plants, rats, and humans. Environ Health Perspect 102 (Suppl 7): 13-20.

64. Schou JS, Jansen JA, Aggerbeck B (1984) Human pharmacokinetics and safety of boric acid. Arch Toxicol Suppl 7: 232-235. [Crossref]

65. WHO (World Health Organization) (1998) Boron, environmental health criteria. World Health Organization, Tech. Report 204. Geneva, Switzerland.
66. Weinthal E, Parag Y, Vengosh A, Muti A, Kloppmann W (2005) The EU Drinking Water Directive: The Boron Standard and Scientific Uncertainty. Eur Env 15: 1-12.

67. BFR (Bundesinstitut für Risikobewertung) (2005) Addition of boric acid or borax to food supplements.

68. Vengosh A, Kloppmann W, Marei A, Livshitz Y, Gutierrez A, et al. (2005) Source of salinity and boron in the Gaza strip: natural contaminant flow in the southern Mediterranean coastal aquifer". Water Resour Res 41(1): 1-19.

69. Sayli, SB, Cöl M, Elhan HA, Genc Y (2005) Assessment of fertility and infertility in boron-exposed Turkish subpopulations 6: relevant data from all centers. $J$ Anka Med School 25: 165-174.

70. Sayli BS, Tüccar E, Elhan AH (1998) An assessment of fertility in boron-exposed Turkish subpopulations. Reprod Toxicol 12: 297-304. [Crossref]

71. Sayli BS, Tüccar E, Ellan AH (2001) An assessment of fertility and infertility in boron exposed Turkish subpopulations: Evaluation of fertility among sibs and in 'borate families. Biol Trace Elem Res 81: 255-267.

72. FAO (Food and Agriculture Organization) (2016) México conmemorará el día mundial de la alimentación en San Felipe del Progreso, Estado de México.

73. Loyola SA, Richardson J, Pelaez BI, Alvarez NJ, Lavis NJ, et al. (2016) The impact of arthritis on the physical function of a rural Maya-Yucateco community and factors associated with its prevalence: a cross sectional, community-based study. Clin Rheumatol 35: S25-S34. [Crossref]

74. de Kruif P (1999) Los cazadores de microbios. EDESA. DF, México pp: 229.

75. WHO (World Health Organization) (2014) World health statistics 2014. Geneva Switzerland pp: 177 .

Copyright: (C2016 Sosa-Baldivia A. This is an open-access article distributed under the terms of the Creative Commons Attribution License, which permits unrestricted use, distribution, and reproduction in any medium, provided the original author and source are credited. 